\title{
PHARMACOMANIPULATION OF HSV-1 INDUCED CHORIORETINITIS IN MICE
}

\author{
AMYNA MERCHANT ${ }^{1}$, JAMES FLETCHER ${ }^{2}$, CARLOS A. MEDINA ${ }^{1}$, \\ RAMZI K. HEMADY ${ }^{3}$ and C. STEPHEN FOSTER ${ }^{1}$ \\ Boston, Massachusetts and Baltimore, Maryland
}

\begin{abstract}
SUMMARY
In the von Szily mouse model, intracameral inoculation of herpes simplex virus type-1 (HSV-1) results in inflammation of the ipsilateral anterior segment with relative chorioretinal sparing and destructive contralateral chorioretinitis. We studied the effect of the systemic antiviral agent acyclovir (ACV) and antiHSV-1 antibody therapy in this model. Contralateral chorioretinitis developed in none of the 18 mice receiving ACV from post-inoculation day (pid) 1 $(p<0.0001)$, in 6 of $10(60 \%)$ mice when treatment was delayed until pid $7(p=0.40)$ and in 14 of $18(77 \%)$ controls. Contralateral disease developed in 8 of 16 $(50 \%)$ mice that received anti-HSV-1 antibody from pid $1(p=0.02)$, in 13 of $16(81 \%)$ treated from pid $5(p$ $=0.64)$, in 7 of $8(87.5 \%)$ treated from pid $7(p=1.0)$ and in 17 of $20(85 \%)$ controls. We conclude that early treatment with ACV or anti-HSV-1 antibody reduces the incidence of contralateral chorioretinitis in mice.
\end{abstract}

Uniocular intracameral inoculation of herpes simplex virus type 1 (HSV-1) into Balb/cByj mice results in ipsilateral inflammation of the anterior segment with relative chorioretinal sparing and contralateral uveitis and destructive retinitis. ${ }^{1}$ This was first described by von Szily in 1924 in rabbits ${ }^{2}$ and is commonly known as the von Szily model. This model closely mimics both HSV-1 induced chorioretinitis and acute retinal necrosis syndrome in humans. ${ }^{3-9}$ Investigators have demonstrated in mice and rabbits that HSV-1 temporally progresses through haematogenous but mostly by neural pathways from the inoculated eye

From: ${ }^{1}$ Hilles Immunology Laboratory, Massachusetts Eye and Ear Infirmary, Harvard Medical School, Boston, Massachusetts; ${ }^{2}$ Department of Otolaryngology, Tufts University, Boston, Massachusetts; ${ }^{3}$ Department of Ophthalmology, Cornea \& Immunology Service, University of Maryland School of Medicine, Baltimore, Maryland, USA.

Correspondence to: C. Stephen Foster, MD, Hilles Immunology Laboratory, Massachusetts Eye and Ear Infirmary, 243 Charles Street, Boston, MA 02114, USA. Tel: +1 (617) 573-3591. Fax: +1 (617) 573-3181. to the contralateral eye. ${ }^{10-14}$ Prevention of this viral spread at certain time intervals after inoculation has been shown to prevent subsequent development of retinal pathology. ${ }^{15-17}$ The exact role of virus versus host immune response in the disease pathogenesis of this model remains unclear. ${ }^{1,10,18-28}$ Previous reports have shown in mice and rabbits that treatment with anti-herpes antibody either before inoculation with HSV-1 or within 24 hours of inoculation prevents the development of necrotising retinitis. ${ }^{24,25,29} \mathrm{We}$ instituted treatment with a systemic anti-viral agent acyclovir or anti-herpes antibody, both of which have been reported to decrease the viral load in the mouse following inoculation with HSV-1. ${ }^{29,30}$ In order to study the effect of early and late therapy on the development of contralateral chorioretinitis the treatment was started at different time intervals following intracameral inoculation of HSV-1 into the ipsilateral eyes of mice.

\section{MATERIALS AND METHODS \\ Animals}

Male and female Balb/cByj mice 7-9 weeks of age were obtained from Jackson Laboratories (Bar Harbour, ME). Mice were housed in micro-isolators mounted in a ventilated animal rack. All mice were handled in accordance with the ARVO Resolution on the Use of Animals in Research.

\section{Virus}

HSV-1 KOS strain was passed twice in Vero cells (American type cell collection, CCL81, Rockville, $\mathrm{MD})$. Virus for all experiments was produced from infected Vero cell monolayers as described previously. ${ }^{18}$

\section{Intracameral HS.V-1 Inoculation}

Balb/cByj mice were anaesthetised with a 1:1 mixture of ketamine hydrochloride and xylazine diluted 1:1 with sterile water. Injection of 
$0.1-0.2 \mathrm{ml}$ was given intraperitoneally using a 30 gauge needle. Mice were then placed under the operating microscope and anterior chamber paracentesis was performed on the right eye using a glass micropipette. A dose of $2 \times 10^{5} \mathrm{PFU}$ of HSV-1 in 5-10 $\mu \mathrm{l}$ of Minimum Essential Medium (MEM; Gibco Laboratories, Grand Island, NY) was then injected into the anterior chamber using a 33 gauge needle attached to a $50 \mu$ l Hamilton syringe.

\section{Pharmacological Agents}

Acyclovir sodium (ACV) $40 \mathrm{mg} / \mathrm{kg}$ body weight was administered three times a day. This dose was based on toxicity studies in mice reported by Machida et al. ${ }^{30} \mathrm{ACV}$ was prepared on a daily basis by dissolving the powder in commercially available sterile water for injection (Abbott Laboratories, IL). Sterile water alone was used to treat the animals in the control group. In the antibody experiment commercially available polyclonal rabbit anti-HSV-1 antibody, $0.2 \mathrm{mg} / 0.1 \mathrm{ml}$, and polyclonal rabbit immunoglobulin fraction $0.2 \mathrm{mg} / 0.1 \mathrm{ml}$ (DAKO, CA), were administered daily to the treated and the control mice respectively. All treatments were given intraperitoneally using a 30 gauge, 1/2 inch needle attached to a $1 \mathrm{~cm}^{3}$ syringe.

\section{Clinical Examination and Observation}

Both eyes of all mice were examined under the operating microscope every other day for 2 weeks following intracameral inoculation with HSV-1, for pupillary dilatation, iris vessel prominence, anterior chamber clouding, retinal opacification and loss of the red reflex. Systemic drug toxicity was evaluated by the appearance of ruffled fur, lethargy, a tense abdomen, gauntness and death. Five mice in group 1 of the ACV experiment were observed on a weekly basis from post-inoculation day (pid) 14 to 40 following cessation of ACV therapy. Animals were killed 14 or 40 days after inoculation with HSV-1 by allowing them to asphyxiate in a dry ice container which had a porous barrier.between the mice and the dry ice.

\section{Virus Recovery Studies}

Two mice, one with and one without contralateral disease, from each group in the ACV experiment were killed on pid 10. The contralateral eyes were harvested and homogenised in $1 \mathrm{~cm}^{3}$ of MEM. The iced homogenate was freeze-thawed three times, centrifuged, plated onto Vero cell monolayers and incubated at $37^{\circ} \mathrm{C}$. The monolayers were examined daily for 5 days for the presence of cytopathic effects typical of a productive viral infection. Plaque assay determination was done as described previously. ${ }^{18}$

\section{Histopathology}

Both eyes of each mouse were enucleated on pid 14 or 40 and processed for histopathological examination as described previously. ${ }^{18}$ Briefly, eyes were fixed in Karnovsky's solution (1\% paraformaldehyde, $1.25 \%$ glutaraldehyde and $0.2 \mathrm{M}$ sodium cacodylate buffer) for 72 hours at $4{ }^{\circ} \mathrm{C}$. The tissue was then rinsed in cacodylate buffer, dehydrated in ascending concentrations of ethanol and embedded in Historesin methacrylate plastic resin (LKB Produkter AB Bromma, Sweden). A Sorvall JB-4 microtome was used to section the tissue, which was then stained using haematoxylin and eosin.

The slides were read by a masked observer and the severity of chorioretinitis was graded as mild, moderate or severe. Mild disease was defined as minimal vasculitis with fewer than 5 cells per highpower field and 1+ vitritis. Moderate disease was characterised as advanced vasculitis with inflammatory cellular infiltrate in all layers of the retina and $2+$ vitritis. Severe disease comprised complete necrosis and destruction of retinal architecture and $3+$ vitritis.

\section{Statistics}

Fisher's exact test was applied to determine whether the incidence of chorioretinitis between the different groups compared with their respective controls was statistically significant at $p<0.05$.

\section{EXPERIMENTAL DESIGN \\ Acyclovir Experiments}

ACV was administered intraperitoneally, three times a day starting on day 1 (group 1) or day 7 (group 2) after inoculation with HSV-1. Treatment was continued until pid 13. Days 1 and 7 were chosen to coincide with the early and late waves of HSV-1 dissemination to the contralateral eye. ${ }^{10}$ Mice in the control group were treated three times a day with sterile water alone. All animals were followed biomicroscopically as described above. Contralateral eyes from two mice, one diseased and one normal, were enucleated on day 10 and processed for virus recovery studies. All other animals were killed on pid 14 , and both eyes enucleated and processed for histopathological examination. Five unaffected mice from group 1 were observed until pid 40 following cessation of ACV therapy on pid 14 .

\section{Anti-HSV-1 Antibodies Experiments}

Rabbit anti-HSV-1 antibody was administered intraperitoneally once daily from day 1 (group 1 ), day 5 (group 2) and day 7 (group 3) after inoculation with HSV-1. Treatment was continued until pid 13. Controls were treated with rabbit immunoglobulin fraction from pid 1-13. All mice tolerated the therapy well. Mice were followed as described above and were killed on pid 14. Both eyes were 
enucleated and processed for histopathological examination.

\section{Acyclovir Experiments}

\section{RESULTS}

The results of treatment with ACV are summarised in Table I. Contralateral chorioretinitis developed in none of the 18 mice receiving ACV from pid 1 $(p<0.0001)$, in 6 of $10(60 \%)$ mice when treatment was delayed until pid $7(p=0.40)$ and in 14 of 18 $(77 \%)$ controls. Weight loss was observed in all mice treated with ACV from day 1 following inoculation with HSV-1. Three mice died in the early treatment group either secondary to ACV toxicity or from peritonitis from intraperitoneal injections. A statistically significant difference in disease incidence was present between group 1 and the controls $(p<0.0001)$. None of the 5 mice from this group that were observed until pid 40 developed contralateral disease following cessation of ACV therapy on pid 14. The incidence of contralateral disease in group 2 was lower than in the controls but the difference was not statistically significant $(p=0.40)$.

Histopathological examination by a masked observer revealed severe destruction of the chorioretinal tissues in all the control eyes which had shown clinical evidence of chorioretinitis. The severity of retinitis in the affected contralateral eyes of treated mice, however, varied from mild to severe. There was no statistically significant difference between the severity of contralateral retinitis in the diseased eyes of treated mice versus affected eyes of untreated control mice (data not shown).

Virus recovery studies revealed no productive infection on Vero cell culture with eyes obtained from the mice in the early or late treatment groups. From the two eyes in the control mice $550 \mathrm{PFU} / \mathrm{ml}$ virus was recovered.

\section{Anti-HSV-1 Antibody Experiment}

The results of treatment with anti-HSV-1 antibody are summarised in Table II. All mice tolerated antibody therapy well. Contralateral chorioretinitis developed in 8 of 16 mice (50\%) in group 1, 13 of 16 mice $(81 \%)$ in group 2 and 7 of 8 mice $(87.5 \%)$ in group 3. Sixteen of 18 (88\%) control mice developed contralateral disease. A statistically significant difference in disease incidence was present only between group 1 and the controls $(p=0.02)$. Clinically the

Table I. Acyclovir experiment results

\begin{tabular}{lccl}
\hline Mouse & Days p.i. $^{\mathrm{a}}$ & Chorioretinitis & $p$ value $^{\mathrm{b}}$ \\
\hline Controls & & $14 / 18(77 \%)$ & \\
Group 1 & $1-13$ & $0 / 18$ & 0.0001 \\
Group 2 & $7-13$ & $6 / 10(60 \%)$ & 0.40 \\
\hline
\end{tabular}

${ }^{\mathrm{a}}$ Duration of drug therapy following inoculation with HSV-1.

${ }^{\mathrm{b}} p$ value versus controls using Fisher's exact test. Significance: $p<0.05$. time of onset of contralateral disease was similar in the treated and the control mice.

Histopathological examination revealed findings similar to those described above for the ACV experiments. There was no statistically significant decrease in the severity of retinitis in the treated mice which developed contralateral disease versus affected controls (data not shown).

\section{DISCUSSION}

Reports of chorioretinitis induced by the herpes group of virus (herpes simplex type 1 and 2 and varicella zoster virus) have been increasing and involve a wide spectrum of patients including neonates, ${ }^{31}$ immunocompromised patients, $, 3,32,33$ patients with herpetic encephalitis $s^{19,34,35}$ and immunocompetent healthy adults. ${ }^{4-7,9}$ The disease frequently appears in the second eye at a variable time following the initial presentation. Treatment strategies have included observation, topical and systemic antiviral agents with or without corticosteroids, early surgery and laser or cryotherapy to prevent detachment of the necrotic retina. A standardised approach is lacking and severe loss of vision is common.

We studied the effects of two therapeutic strategies - systemic ACV or anti-HSV-1 antibody - both of which have been reported to effectively decrease the viral load following inoculation of HSV-1 in mice. ${ }^{29,30}$

Viral dissemination from the ipsilateral to the contralateral eye in the mouse model has been reported to occur in two waves: an early low-titre wave within 24 hours of inoculation and a later hightitre wave from pid $7-10 .^{10}$ Whittum et al. ${ }^{1}$ detected HSV-1 in the uninoculated eye on pid 5. Viral spread to the contralateral eye occurs mostly by the neuronal route between pid 5 and pid $7 .{ }^{12-14} \mathrm{We}$ instituted the late treatment with systemic ACV or anti HSV-1 antibody therapy on pid 5 or 7 , which correlates with the 'second wave' of viral spread to the uninoculated eye.

In this study, early treatment (i.e. within 24 hours of inoculation with HSV-1) with a systemic antiviral agent (ACV) or anti-HSV-1 antibody was effective in preventing contralateral chorioretinitis in mice. This is the first report describing the effect of treatment with ACV in this mouse model. Delaying ACV therapy until pid 5 did not confer protection to

Table II. Anti-HSV-1 antibody experiment results

\begin{tabular}{lccc}
\hline Mouse & Days p.i. $^{\mathrm{a}}$ & Chorioretinitis & $p$ value $^{\mathrm{b}}$ \\
\hline Controls & & $16 / 18(88 \%)$ \\
Group 1 & $1-10$ & $8 / 16(50 \%)$ & 0.02 \\
Group 2 & $5-10$ & $13 / 16(81 \%)$ & 0.64 \\
Group 3 & $7-10$ & $7 / 8(88 \%)$ & 1.00 \\
\hline a Duration of drug therapy following inoculation with HSV-1. \\
b value versus controls using Fisher's exact test. Significance: \\
$p<0.05$.
\end{tabular}


the contralateral retina. Virus recovery studies revealed no detectable virus in the contralateral eyes of the treated mice. Our findings are consistent with the findings reported in retrospective clinical studies by Palay et al. ${ }^{17}$ and Crapotta et al. ${ }^{36}$ who reported decreased risk of developing contralateral acute retinal necrosis when systemic ACV therapy was instituted at the time of initial presentation in patients with acute retinal necrosis. The protective effect of the treatment was stated to be most pronounced during the first 14 weeks of therapy in the first report. ${ }^{17}$ All patients in the latter study ${ }^{36}$ were first seen when they had limited retinal involvement in the first eye and none of these patients developed contralateral disease. Both these reports concluded that decreasing viral replication during the first few weeks following unilateral involvement by aggressive systemic antiviral therapy with ACV prevented virus dissemination to the fellow eye and consequently lowered the risk of contralateral retinal involvement. In this study both early and late ACV treatment groups had decreased viral load in the contralateral eyes on pid 10 .

In this study we found that early treatment with anti-HSV antibody was protective against contralateral chorioretinitis. This confirms a previous report by Atherton ${ }^{29}$ demonstrating the protective effect of passive transfer of monoclonal antibody specific for HSV glycoprotein D against contralateral retinal necrosis in the von Szily mouse model when the antibody was administered either 2 hours before virus inoculation or 24 hours after virus inoculation. Her findings, however, were in contrast to an earlier report from her laboratory in which they had stated that passive immunisation with anti-HSV antibody does not prevent contralateral retinal necrosis in the von Szily mouse model. ${ }^{37}$ They attributed their earlier finding to a lower affinity or lesser neutralising capability of the polyclonal antibody used in that study. Previously our laboratory has shown the protective effect of anti-HSV hyperimmune serum in the von Szily model, ${ }^{24}$ and the protective effect of early (pid 0-4) anti-glycoprotein D antibody against HSV-2 chorioretinitis in newborn rabbits has also been reported. ${ }^{25}$

Unlike previous reports this study also tested the efficacy of delayed therapy with anti-HSV-1 antibody to determine the usefulness of this treatment modality in a clinical setting in which patients with acute retinal necrosis have significant retinal involvement and virus replication has already occurred at the time of initial presentation. We did not find a significant reduction in the incidence of contralateral retinitis following delayed therapy with anti-HSV-1 antibody.

To date there is no clear explanation for the pathogenesis of contralateral retinitis and relative sparing of ipsilateral retina after HSV inoculation. Evidence suggests that the presence of live virus in the posterior segment of the contralateral eye is necessary though not sufficient for the development of chorioretinitis. ${ }^{26}$ Recent work from our laboratory has demonstrated protection of the contralateral retina in mice following intravitreal injection of CD11, an antibody against immune effector cells. ${ }^{28}$ This suggests a role for immune-mediated destruction of the retina.

Because of the striking protective effect on the fellow eye following early therapy with ACV and anti-HSV antibody it seems prudent to extrapolate these results to patients with acute retinal necrosis who present early in their disease course with unilateral involvement. However, specific immune therapy may be more beneficial in the majority of clinical situations where patients are likely to present when virus replication and dissemination to the fellow eye may already have occurred. Severity of tissue destruction in the fellow eye may then be curtailed by local or systemic immunomodulation of the effector cells and their cytokines, which in fact may be the more important culprits in causing damage to the retinal tissue.

The authors acknowledge the assistance of Tong Zhen Zhao, MD, and Arnd Heiligenhaus, MD.

Key words: Acyclovir, Anti-HSV-1 antibody, Chorioretinitis, HSV-1, Mouse, von Szily model.

\section{REFERENCES}

1. Whittum JA, McCulley JP, Niederkorn JY, Streilen JW. Ocular disease induced in mice by anterior chamber inoculation of herpes simplex virus. Invest Ophthalmol Vis Sci 1984;25:1065-73.

2. von Szily A. An experimental endogenous transmission of infection from bulbus to bulbus. Klin Monatsbl Augenheilkd 1924;75:593-602.

3. Pepose JS, Hillborne LH, Cancilla PA, Foos RY. Concurrent herpes simplex virus and cytomegalovirus retinitis and encephalitis in the acquired immune deficiency syndrome (AIDS). Ophthalmology 1984;91:1669-77.

4. Ludwig IH, Zegarra H, Zako VN. The acute retinal necrosis syndrome: possible herpes simplex retinitis. Ophthalmology 1984;91:659-64.

5. Freeman WR, Thomas EL, Rao NA, Pepose JS, Trousdale MD, Howes EL, et al. Demonstration of herpes group virus in acute retinal necrosis syndrome. Am J Ophthalmol 1986;102:701-9.

6. Matsuo T, Date S, Tsuji T, Koyama M, Nakayama T, Koyama $\mathrm{T}$, et al. Immune complex containing herpes virus antigen in a patient with acute retinal necrosis syndrome. Am J Ophthalmol 1986;101:368-71.

7. Matsuo T, Nokayama T, Koyama T, Matsuo N. Cytological and immunological study of the aqueous humor in acute retinal necrosis syndrome. Ophthalmologica 1987;195:38-44.

8. de Boer JH, Luyendijk L, Rothova A, Baarsma GS, de Jong PT, Bollemeijer JG, et al. Detection of intraocular antibody production to herpes viruses in acute retinal necrosis syndrome. Am J Ophthalmol 1994;117:201-10. 
9. Lewis ML, Culbertson WW, Post JD, et al. Herpes simplex virus type-1: a cause of the acute retinal necrosis syndrome. Ophthalmology 1989;96:875-8.

10. Atherton SS, Streilein JW. Two waves of virus following anterior chamber inoculation of HSV-1. Invest Ophthalmol Vis Sci 1987;28:571-9.

11. Olson RM, Holland GN, Gross SJ, Bowers WD, Meyers-Elliot RH. Route of viral spread in the von Szily model of herpes simplex virus retinopathy. Curr Eye Res 1987;16:59-62.

12. Vann VR, Atherton SS. Neural spread of herpes simplex virus after anterior chamber inoculation. Invest Ophthalmol Vis Sci 1991;32:2463-72.

13. Bosem EM, Harris R, Atherton SS. Optic nerve involvement in viral spread in herpes simplex virus type 1 retinitis. Invest Vis Sci 1990;31:1683-9.

14. Margolis TP, La Vail JH, Setzer PY, Dawson CR. Selective spread of herpes simplex virus in the central nervous system after ocular inoculation. $J$ Virol 1989;63:4756-61.

15. Whittum-Hudson J, Pepose JS. Immunologic modulation of virus-induced pathology in a murine model of acute herpetic retinal necrosis. Invest Ophthalmol Vis Sci 1987;28:1541-8.

16. Whittum-Hudson J, Farazdaghi M, Prendergast RA. The role for $\mathrm{T}$ lymphocytes in preventing experimental herpes simplex virus type 1 induced retinitis. Invest Ophthalmol Vis Sci 1985;26:1524-32.

17. Palay DA, Sternberg P Jr, Davis J, Lewis H, Holland GN, Mieler WF, et al. Decrease in the risk of bilateral acute retinal necrosis by acyclovir therapy. Am J Ophthalmol 1991;112:250-5.

18. Hemady R, Opremcak EM, Zaltas M, Berger A, Foster CS. Herpes virus type-1 strain influence on chorioretinal disease patterns following intracameral inoculation in Igh-1 disparate mice. Invest Ophthalmol Vis Sci 1987;30:1750-7.

19. Ahmadieh H, Sajjadi SH, Azarmina M, Kalani H. Association of herpetic encephalitis with acute retinal necrosis syndrome. Ann Ophthalmol 1991;23:215-9.

20. Whittum JA, Niederkron JY, McCulley JP, Streilen JW. Intracameral inoculation of herpes simplex virus type 1 induces anterior chamber associated immune deviation. Curr Eye Res 1983;2:691-7.

21. Streilein JW, Atherton S, Vann VA. Critical role for ACAID in the distinctive pattern of retinitis following anterior chamber inoculation of HSV-1. Curr Eye Res 1987;6:127-31.

22. Metzger EE, Whittum JH. The dichotomy between herpes simplex virus type- 1 induced ocular pathology and systemic immunity. Invest Ophthalmol Vis Sci 1987;28:1533-40.

23. Liu Y, Sakai Y, Minagawa H. Induction of bilateral retinal necrosis in mice by unilateral intracameral inoculation of a simplex virus type 1 . Arch Virol 1993;129:105-18.

24. Zierhut M, Tamesis R, Hemady R, Foster CS. Herpes simplex virus retinitis: role of the immune system in the animal experiment. Fortschr Ophthalmol 1991;88: 740-7.

25. Inoue $Y$, Oh OJ, Minasi P. Protective effect of antiglycoprotein D antibody on herpetic chorioretinitis in newborn rabbits. Curr Eye Res 1991; 10(Suppl): 159-65.

26. Streilein JW, Igietseme JU, Atherton SS. Evidence that precursor cytotoxic $\mathrm{T}$ cells mediate acute necrosis in HSV-1 infected retinas. Eye Res 1991;10(Suppl):81-6.

27. Foster CS, Zierhut M, Wu H, Jabbur N. Murine acute retinal necrosis. Trans Am Ophthalmol Soc 1991; $89: 251-65$

28. Berra A, Rodriguez A, Heiligenhaus A, Pazos B, Van Rooijen, Foster CS. The role of macrophages in the pathogenesis of HSV-1 induced chorioretinitis in Balb/ c mice. Invest Ophthalmol Vis Sci 1994;35:2990-8.

29. Atherton SS. Protection from retinal necrosis by passive transfer of monoclonal antibody specific for herpes simplex virus glycoprotein D. Curr Eye Res 1992;11:45-52.

30. Machida H, Ikeda $\mathrm{T}$, Ashida N. Comparison of antiviral efficacies of 1-beta-D-arabinofruanosyl-E-5(2-bromovinyl) uracil (brovavir) and acyclovir against herpes simplex virus type- 1 infection in mice. Antiviral Res 1987;14:99-105.

31. Mousal DK, Missal SR. Panuveitis and retinitis in neonatal herpes simplex infection. J Pediatr Ophthalmol Strabismus 1979;16:7-9.

32. Pass RF, Whitley RJ, Whelchel JD, Diethelm AG, Reynolds DW, Alford CA. Identification of patients with increased risk of infection with herpes simplex virus after renal transplantation. $J$ Infect Dis 1979;140:487-92.

33. Uninsky E, Jampol LM, Kaufman F, Naraqi S. Disseminated herpes simplex infection with retinitis in a renal allograft recipient. Ophthalmology 1983;90: $75-8$.

34. Minckler DS, McLean EB, Show CM, Hendrickson A. Herpes virus hominis encephalitis and retinitis. Arch Ophthalmol 1976;94:89-95.

35. Bloom JN, Katz JI, Kaufman HE. Herpes simplex retinitis and encephalitis in an adult. Arch Ophthalmol 1977;95:1798-9.

36. Crapotta JA, Freeman WR, Feldman RM, Lowder CY, Ambler JS, Parker CE, Meisler DM. Visual outcome in acute retinal necrosis syndrome. Retina 1993;13: 208-13.

37. Dix RD, Atherton SS, Streilen JW. Effect of passively transferred neutralising antibody on the development of herpes simplex type-1 (HSV-1) retinitis. Invest Ophthalmol Vis Sci 1986;27(Suppl):124. 